\title{
Story Maps \& Co. The state of the art of online
} narrative cartography

Story Maps \& Co. Un état de l'art de la cartographie des récits sur Internet Story Maps \& C. Situación actual de la cartografías narrativas en Internet

\section{Sébastien Caquard and Stefanie Dimitrovas}

\section{OpenEdition}

\section{Journals}

Electronic version

URL: http://journals.openedition.org/mappemonde/3386

DOI: $10.4000 /$ mappemonde.3386

ISSN: $1769-7298$

\section{Publisher}

UMR ESPACE

Electronic reference

Sébastien Caquard and Stefanie Dimitrovas, « Story Maps \& Co. The state of the art of online narrative cartography », Mappemonde [Online], 121 | 2017, Online since 01 July 2017, connection on 10

December 2020. URL : http://journals.openedition.org/mappemonde/3386 ; DOI : https://doi.org/ 10.4000/mappemonde.3386

This text was automatically generated on 10 December 2020.

\section{cc) (†) (-)}

La revue Mappemonde est mise à disposition selon les termes de la Licence Creative Commons Attribution - Pas d'Utilisation Commerciale - Partage dans les Mêmes Conditions 4.0 International. 


\title{
Story Maps \& Co. The state of the art of online narrative cartography
}

\author{
Story Maps \& Co. Un état de l'art de la cartographie des récits sur Internet \\ Story Maps \& C. Situación actual de la cartografías narrativas en Internet
}

Sébastien Caquard and Stefanie Dimitrovas

\section{Introduction}

1 In November 2013, Google enhanced its mapping services by launching Tour Builder ${ }_{2}$ an application dedicated to mapping stories. A year earlier, in October 2012, ESRI - a leader in the world of Geographic Information Systems (GIS) since its launch of ArcInfo in the early 1980's - had already created its own application for narrative mapping: Story Maps. The arrival of these two giants in the world of narrative cartography added to the already diverse field of online story mapping applications such as Neatline, Tripline, MapStory, Maptia, Trippermap, and Atlascine, pointing to a real surge in this new form of cartographic expression.

2 The different locations of the trajectory of a fictional hero or a migrant across multiple borders are straightforward to portray using these tools. However, it becomes much more complicated to map the emotions and perceptions experienced during these journeys, as well as the associated spatiotemporal structures unique to every story. Generally, space (and even time) is neither Cartesian, nor continuous in narratives. It varies due to the fluid structure of events, descriptions, memories, and the imaginary. Maps and stories simply do not have the same geography. Although the relevance of mapping stories for understanding social phenomena is increasingly recognized (Kwan and Ding 2008; Pearce and Hermann 2010; Seemann 2012; Bodenhamer et al. 2015), it is worth asking at what point online story mapping applications can deal with the spatiotemporal complexity of stories.

3 To assist in answering this question, we have systematically mapped the same story using six online story mapping applications. The story we have chosen is a part of the 
life story of a Rwandan refugee living in Canada. This captivating story is one of 500 collected between 2007 - 2012 in the form of video interviews recorded by the Center for Oral History and Digital Storytelling (COHDS) at Concordia University. In the first section of this article, we start by discussing the main methodological challenges of mapping stories, and in particular of mapping life stories. In the second section, we present the different mapping applications we studied as well as how we structured our comparative analysis for the six applications. In the third and final section we provide a synthesis of the results, which highlight the potentialities as well as the limitations of each tool used in relation to the type of story to be mapped. This synthesis can serve as a practical guide for potential users of these applications, as well as to stimulate reflections for the advancement of narrative cartography.

\section{Mapping stories: context and methodological questions}

\section{Theoretical context}

As emphasized by writer Pierre Sengès (2011), mapping stories, both fictional and nonfictional, has marked the history of humanity since at least ancient times. A notable example of this is the unwavering interest in situating Homer's stories, and notably that of Ulysses (Sengès 2011; Evans and Jasnow, 2014). The functions and objectives inherent in mapping a story can go far beyond simply satisfying the curiosity of the researcher, illustrating the tales of trips, or recording memories from our last vacation. For example, the process can take on a heuristic quality to better understand the narrative structures of a particular work or author. Since the end of the $20^{\text {th }}$ century, the map has become the primary tool for analysis in the field of literary geography (Morretti 1999, 2005; Piatti et al. 2009; Hui 2009; Cooper and Gregory 2011; Wells 2012). For indigenous communities, where oral traditions have mythical, historical, as well as spatial functions, story mapping is increasingly used for political and legal purposes. The map becomes the tangible link between the oral story and the ancestral occupation of the land. It can thus act as leverage for reclaiming land. Story mapping can also have a therapeutic function for stories with tragic elements, like stories of violent conflicts (Littman 2011), testimonials of Holocaust survivors (Knowles et al. 2015), or the narratives of migrants and refugees (Mekdjian et al. 2014). Mapping refugee stories can also "... elucidate fascinating life journeys and identify 'dense points' ("points denses") or locations rich with associated values, personal perceptions, identity projections, and/or emotional experiences." (Rossetto 2014, 89, translation ours)

5 These less tangible aspects of geography are what deep mapping seeks to address (Bodenhamer et al. 2015). As emphasized by Susan Naramore Maher (2014), deep mapping is characterized by the interaction of a plethora of stories, of all types individual, collective, fictional, documentary, and even mythical - in order to understand "quintessential" aspects of a place. This acknowledgment of the importance of personal stories in our understanding of places is part of a lineage of works from difFerent researchers and intellectuals such as Guy Debord, Michel DeCerteau, Yi Fu Tuan, or Edward Soja, and more recently in the spatial theories developed by Tim Cresswell (2004) or Doreen Massey (2005). Deep mapping is therefore not limited to the tangible and material but also integrates personal, emotional, and 
cultural relationships to places. Through this combination of the material and immaterial, "[d]eep maps reflect the complex interaction of the physical and human environments and their relations and behaviors that are nuanced, nonlinear, branching, and so very difficult to map." (Harris 2015, 33)

Mapping stories and their less tangible dimensions is indeed a complex task, which explains in part why the expression "deep mapping" could seem strange for describing a practice that very rarely includes maps (Wood 2015). Transforming stories into maps is particularly challenging due to the tension between the blurry, personal, and emotional dimensions of stories and the characteristics of fixity, hierarchy, and quanti fication inherent in conventional cartographic representations. Deep mapping cannot be reduced to simply geolocating points associated to a list of the toponyms mentioned in a story onto a Google map, with associated photos, videos, or passages of text. It first requires a rigorous process of identifying and characterizing places.

\section{Identifying and characterizing places in the story}

7 Although different types of narrative spaces have been identified in stories (see Bodenhamer 2015), there is no ontology of geographic narrative objects. In other words, places mentioned in a story can take on varied and subtle forms that are often di FFIcult to identify and circumscribe. Some places are the setting for events in the story, others are simply mentioned; some place names are specific (e.g. the name of a city), others are generic (e.g. the lake, the neighborhood); some place names are geographically precise (e.g. an address), others are much less so (e.g. a country); some places are described in rich detail by the storyteller, while others are simply named; some place names have disappeared, and others have been modified, etc. In short, the identification and circumscription of the locations in a story involve a number of decisions. Despite the important progress that has been made in the field of automatic recognition of place names in text, especially with geoparsing and natural language processing techniques, identifying these different kinds of locations in a story often requires the participation of an analyst, or person who will listen to or read the story with the intention of identifying the locations as well as their difFerent characteristics, especially their temporal ones.

Indeed, mapping stories requires integrating temporality into the map space. The meaning of a place cannot truly be revealed without the integration of both space and time (Bodenhamer et al. 2015), which can be accomplished by identifying spatiotemporal events in a story (Massey 2005). In order to do this, it is essential to characterize the different temporal dimensions of the story. In a life story, the temporal framework is influenced by the memory of the storyteller, by the links that could exist between different events in difFerent moments in time, as well as by the structure of the narrative, for example that of an interview. Even if a life story follows a chronological structure, there still tend to be temporal shifts such as flashbacks. Like space, the time in a story can be very precise or extremely vague on many levels, such as the duration of the event or where it fits in the chronology. Again, much of this characterization will depend directly on the analyst's choices.

With simply a quick review of the main methodological challenges that arise at the start of the mapping process, the analyst, by their many choices, would appear to play a fundamental role in the way the story is transformed, first into spatiotemporal units 
and then into cartographic objects. It is therefore important to define a methodology that reduces the analyst's role, while still recognizing their impact on the final result. It is with these factors in mind that we defined a methodology for identifying and characterizing locations in the life story of a Rwandan refugee.

\section{The mapped story}

OG is a Rwando-Canadian born in 1951 in Kibuye, Rwanda. His father died when he was only 5 years old, so his older brother took responsibility of his education. It was with him that OG left Rwanda and the rest of his family in 1960 to flee the violence against the Tutsis, landing in the neighboring Zaire (now the Democratic Republic of Congo). OG spent the rest of his childhood there until he moved to difFerent countries in Africa, namely Ethiopia and Libya, in the first twenty years of his adulthood. Finally, following the 1994 genocide, OG and his family left Africa altogether to immigrate to Canada, where they still live today. This fascinating life story, which extends over a period of 5 hours and 10 minutes, is one of the 500 stories collected between 2007 and 2012 by the Center for Oral History and Digital Storytelling (COHDS) of Concordia University. We chose this story - and more specifically, one of the more geographically rich periods as detailed below - for our comparative analysis due it's geographic richness.

Before mapping this story, it had to be transformed into mappable, spatiotemporal units, structured as a database. This database took the form of a spreadsheet, where each listed location was characterized by difFerent types of information from the story: the geographic coordinates of the location, when they could be identified (with the intermediary of a gazetteer, or geographic index); the level of precision of the location, from very local (e.g. an address) to very imprecise (e.g. a continent); the exact moment of the interview when the location is mentioned; any temporal information when possible; a brief summary of the context of the location in the narrative; and finally the analyst's comments (see table 1). This databasification revealed 79 (unrepeated) locations in the story. To keep the comparative mapping process manageable in terms of time, we selected the period of OG's life when he was based in Ethiopia, from 1975 1985. This period of his life contains 12 of the 79 locations and is spatially discrete.

Table 1. Example of the locations identified in the story and their structure in the database

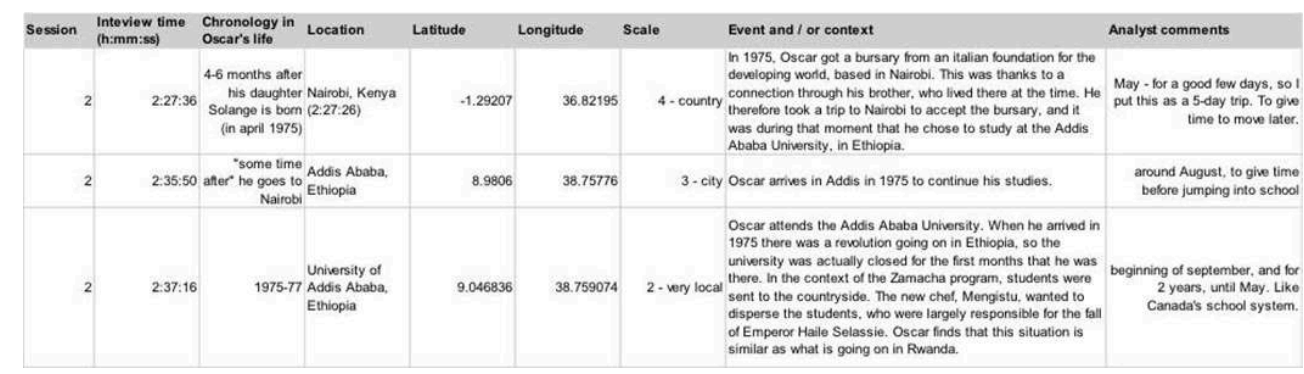




\section{Cartographic tools and methodology for comparative analysis}

\section{Cartographic tools}

12 Even if there exists a number of online cartographic applications that could be used to map stories, such as Carto DB, our analysis focuses on applications specifically created for mapping stories. Among the eight applications initially chosen, two were quickly revealed to be inappropriate ${ }^{1}$; we therefore worked with six in more detail (see table 2). The first one is Tripline. This open-source application was conceived by Byron Dumbrill in 2010, primarily for mapping trips and personal stories. The second, Atlascine, was developed by Sebastien Caquard and Jean-Pierre Fiset for geolocating the scenes in films with an open-source software (Nunaliit), designed at Carleton University. The third application is Mapstory. It is also an open-source application, created by Christopher Tucker and launched in April 2012 by the Mapstory Foundation, initially conceived for collecting stories about global change in the form of maps. Neatline is the fourth application studied. It is also an open-source application, developed by the University of Virginia Library Scholars' Lab. It is designed primarily for archiving and presenting collections of historical artifacts, both temporally and cartographically. The fifth is Story Maps, launched in 2012 by the company ESRI. This application is not open source since it uses proprietary software. It has been designed to improve the communication and diffusion of the results of spatial analysis. Lastly, the sixth application in this analysis is Tour Builder. This application was launched in November 2013 by Google, and uses Google Earth as the cartographic framework. The original objective was to allow American army veterans to map stories of memories associated to their duty stations. A synthesis of the different characteristics of each application is provided in table 2 . This synthesis was made from a systematic analysis of the documentation available online for each application.

Table 2. Overview of the different applications

\begin{tabular}{|c|c|c|c|c|c|c|}
\hline & Google Tour Builder & Tripline & Mapstory & ESRI Story Maps & Atlascine & Neatline \\
\hline Link & \begin{tabular}{|c|} 
hittps:///hourbuilder withgo \\
ogle.com
\end{tabular} & hittp://wwww.tripline. net/ & http://mapstory.org/ & \begin{tabular}{|c|} 
hitpp://storymaps, arcgis.c \\
omieni
\end{tabular} & $\begin{array}{l}\text { hittp://atlascine3,classon } \\
\text { e-tech.com/ }\end{array}$ & http://neatline.org/ \\
\hline Date of publication & Nov-13 & Aug-10 & Apr-12 & Oct-12 & $\begin{array}{l}2010 \text { (Atlascine2: } \\
\text { 2013 / Atlascine3: } \\
\text { 2014) }\end{array}$ & Jul-12 \\
\hline Type of company & large corporation & small-scale & $\begin{array}{c}\text { Foundation / university } \\
\text { / community }\end{array}$ & large corporation & university & university \\
\hline $\begin{array}{l}\text { Number of maps } \\
\text { published so far }\end{array}$ & 36 & 259 & 738 & 894 & 26 & 14 (number of demos) \\
\hline $\begin{array}{c}\text { Main types of maps } \\
\text { made }\end{array}$ & $\begin{array}{c}\begin{array}{c}\text { Environment, culture } \\
\text { and society, personal } \\
\text { stories }\end{array} \\
\end{array}$ & $\begin{array}{l}\text { Adventures, travels, } \\
\text { fiction }\end{array}$ & wide range & wide range & film, fiction & history \\
\hline Goal(s) & $\begin{array}{c}\text { share your life with } \\
\text { others using Google } \\
\text { Earth }\end{array}$ & $\begin{array}{l}\text { share your life with } \\
\text { people you care about }\end{array}$ & $\begin{array}{l}\text { unify knowledge about } \\
\text { global change }\end{array}$ & $\begin{array}{l}\text { promote that GIS tools } \\
\text { can be effective for } \\
\text { communications }\end{array}$ & $\begin{array}{c}\text { Mapping narratives to } \\
\text { better understand } \\
\text { places }\end{array}$ & $\begin{array}{l}\text { Map your collections } \\
\text { of archives and } \\
\text { artifacts with timelines }\end{array}$ \\
\hline $\begin{array}{l}\text { Where is the data } \\
\text { stored (and who } \\
\text { owns the rights)? }\end{array}$ & $\begin{array}{c}\text { On one of Google's } \\
\text { servers around the } \\
\text { world (The user owns } \\
\text { the rights but } \\
\text { authorizes Google to } \\
\text { use and distribute the } \\
\text { content.) }\end{array}$ & $\begin{array}{c}\text { On Tripline's servers } \\
\text { and third parties (By } \\
\text { posting data the user } \\
\text { gives Tripline the right } \\
\text { to use and distribute } \\
\text { content.) }\end{array}$ & $\begin{array}{c}\text { On a server run by } \\
\text { Mapstory (Mapstory } \\
\text { hosts the data but the } \\
\text { user creates and } \\
\text { manages the data.) }\end{array}$ & $\begin{array}{l}\text { ESRI Cloud (The } \\
\text { mapmaker owns the } \\
\text { rights but authorizes } \\
\text { ESRI to use and } \\
\text { distribute the data.) }\end{array}$ & $\begin{array}{c}\text { In a Google Sheet } \\
\text { (The mapmaker owns } \\
\text { the rights but } \\
\text { authorizes Google to } \\
\text { use and distribute the } \\
\text { data.) }\end{array}$ & $\begin{array}{c}\text { On an open-source } \\
\text { server (managed by } \\
\text { the mapmaker or by a } \\
\text { service provider, e.g. } \\
\text { AcuGIS) }\end{array}$ \\
\hline Free & Yes & Yes & Yes & Yes - limited version & Yes & $\begin{array}{l}\text { Yes (but requires an } \\
\text { open-source server) }\end{array}$ \\
\hline Open-source & No & Yes & Yes & No & $\begin{array}{c}\text { Yes (application) / No } \\
\text { (Google Sheets) }\end{array}$ & Yes \\
\hline
\end{tabular}




\section{The comparative analysis grid}

13 In order to evaluate the potentialities and limits of these applications, each was used for approximately twelve hours (more in the case of Neatline) to map the selected section of OG's story. For comparability, we have evaluated them systematically with the help of a series of qualitative criteria, which can be summarized by the following questions:

- Does the application include a geocoding tool allowing the user to assign geographic coordinates to each place name identified in the story?

- Can the user import pre-existing geographic databases (e.g. .csv, .shp, .kml)?

- Does it automatically link locations to show movement or trajectories?

- Does it offer a wide range of cartographic options for controlling the graphic semiotics of the entities represented (e.g. choice of symbols, colors, levels of opacity)?

- Does it provide the option of representing quantitative data in an automated way (e.g. proportional symbols)?

- Does it allow the user to integrate difFerent types of media (e.g. photos, videos, audio, text) and to associate them to the geographic elements of the map?

- Does it ofFer any way to communicate spatial and / or temporal vagueness?

- Does it offer the possibility to differentiate the locations visited by the narrator with locations simply mentioned in the story for various reasons?

- Does it allow the user to combine different stories on the same map in order to see similarities, difFerences and / or spatial overlaps?

- Does it offer options for representing time?

- Does it allow for maps to be created collaboratively?

14 These questions were answered qualitatively (see table 3) and in so doing, we observed the emergence of three families of story mapping applications, which we will now present in more detail. 
Table 3. Comparative synthesis of the applications

\begin{tabular}{|c|c|c|c|c|c|c|}
\hline & Google Tour Builder & Tripline & Mapstory & ESRI Story Maps & Atlascine & Neatline \\
\hline $\begin{array}{l}\text { Easy to use ? (for the } \\
\text { mapmaker) }\end{array}$ & Yes & Yes & Not really & Yes (for simple maps) & Not really & No \\
\hline Geocoding? & Yes & Yes & Yes & Yes & Yes & No \\
\hline $\begin{array}{l}\text { Can ge ographic data } \\
\text { be uploaded? }\end{array}$ & Yes $(e . g . \mathrm{kml})$ & No & yes (.shp or. csv) & Yes (e.g. shp) & Not really & no \\
\hline Can we link places? & Yes (as trajectories) & $\begin{array}{c}\text { Yes (as trajectories -e.g. } \\
\text { aerial, driving route) }\end{array}$ & № (only manually) & $\begin{array}{l}\text { Yes but requires } \\
\text { multiple steps (e.g. to } \\
\text { import links ffrom } \\
\text { ArcGIS, or drawing them } \\
\text { manually) }\end{array}$ & $\begin{array}{c}\text { Yes (locations are } \\
\text { automatically linked, but } \\
\text { trajectories are not } \\
\text { avaliable) }\end{array}$ & № (only manually) \\
\hline $\begin{array}{c}\text { Cartographic options } \\
\text { Isymbols }\end{array}$ & Few options & Few options & $\begin{array}{c}\text { Some options } \\
\text { (especially wth .shp } \\
\text { fles) }\end{array}$ & $\begin{array}{c}\text { Some options } \\
\text { (especially with shp } \\
\text { flies) }\end{array}$ & $\begin{array}{c}\text { Some options (but no } \\
\text { graphic interface) }\end{array}$ & \begin{tabular}{|c}
$\begin{array}{c}\text { Some options (but no } \\
\text { legend) }\end{array}$ \\
\end{tabular} \\
\hline $\begin{array}{l}\text { Can we represent } \\
\text { quantitative data? } \\
\text { (e.g. proportional } \\
\text { symbols, shades) }\end{array}$ & No & No & \begin{tabular}{|}
$\begin{array}{c}\text { Yes (only if you import } \\
\text { files e.g. shp) }\end{array}$
\end{tabular} & \begin{tabular}{|} 
Yes (only if you import \\
files e.g. shp)
\end{tabular} & \begin{tabular}{|c|} 
Yes (proportional \\
symbols representing \\
the time associated to a \\
place and the number of \\
links)
\end{tabular} & No \\
\hline $\begin{array}{l}\text { Multimedia options } \\
\text { (e.g. photos, video, } \\
\text { audio)? }\end{array}$ & Many & Many & Many & Many & None & Many \\
\hline $\begin{array}{c}\text { Can we represent } \\
\text { spatial and / or } \\
\text { temporal vagueness? }\end{array}$ & $\begin{array}{c}\begin{array}{c}\text { Not really (but there is } \\
\text { the option of importing } \\
\text {.kml files with varying } \\
\text { opacities) }\end{array} \\
\end{array}$ & No & Not really & $\begin{array}{l}\text { Yes (e.g. choosing } \\
\text { visualization at different } \\
\text { zoom levels, opacities, } \\
\text { choice of base map) }\end{array}$ & $\begin{array}{l}\text { In a limited way (opacity } \\
\text { and choice of base map) }\end{array}$ & $\begin{array}{l}\text { Yes (e.g. choosing } \\
\text { visualization at differen } \\
\text { zoom levels, choice of } \\
\text { base map) }\end{array}$ \\
\hline $\begin{array}{l}\text { Can we distinguish } \\
\text { between mentioned } \\
\text { and visited locations? }\end{array}$ & Yes (manually) & No & Yes (manually) & Yes (manually) & Yes (automatically) & Yes (manually) \\
\hline $\begin{array}{c}\text { Can we connect } \\
\text { different stories on a } \\
\text { unique map? (e.g. } 2 \\
\text { characters) }\end{array}$ & No & No & $\begin{array}{l}\text { Yes (can upload multiple } \\
\text { flies / layers) }\end{array}$ & \begin{tabular}{|c|} 
Partially (possibility of \\
creating multiple lines I \\
points for different \\
storyes)
\end{tabular} & Yes & \begin{tabular}{|c} 
Partially (possibility of \\
creating multiple lines \\
points for different \\
storyes)
\end{tabular} \\
\hline $\begin{array}{l}\text { Can we represent the } \\
\text { time associated to } \\
\text { each place? }\end{array}$ & Only chronologically & Only chronologically & $\begin{array}{l}\text { Yes (at least } 1 \text { map } \\
\text { layer must have a } \\
\text { temporal component. } \\
\text { There is also an } \\
\text { interactive timeline.) }\end{array}$ & Only chronologically & \begin{tabular}{|c} 
Yes (each object must \\
have a duration)
\end{tabular} & $\begin{array}{l}\text { Yes (Each object can } \\
\text { show up on an } \\
\text { interactive timeline.) }\end{array}$ \\
\hline $\begin{array}{l}\text { Can the maps be } \\
\text { created } \\
\text { collaboratively? }\end{array}$ & No & No & Yes & Yes & Yes & Yes \\
\hline Summary & $\begin{array}{l}\text { Simple but limited (e.g. } \\
\text { for touristic stories with } \\
\text { clear trajectories) }\end{array}$ & $\begin{array}{l}\text { Simple but limited (e.g. } \\
\text { for non-fictional stories } \\
\text { with clear trajectories) }\end{array}$ & \begin{tabular}{|c|} 
Versatile, well adapted \\
to temporal \\
representations (e.g. \\
stories about social or \\
environmental change). \\
but some technical bugs \\
\end{tabular} & $\begin{array}{c}\text { Versatile - many } \\
\text { developed story map } \\
\text { apps for easy use and a } \\
\text { variety of approaches } \\
\text { and clean graphics }\end{array}$ & $\begin{array}{c}\text { Specialized - for spatial } \\
\text { analysis of narratives, } \\
\text { but no multimedia } \\
\text { options, and not very } \\
\text { intuitive to use }\end{array}$ & \begin{tabular}{|c|} 
Specialized - for \\
historical analysis and \\
archiving of collections \\
of artifiacts. Lots of \\
potential for different \\
types of stories but \\
complex to employ.
\end{tabular} \\
\hline
\end{tabular}

\section{Results and discussion}

\section{Simple applications for visualizing stories}

15 The first family consists of applications that use the map primarily as a way to organize a story into a simple, linear spatial structure. This family includes Tripline (figure 1) and Google Tour Builder (figure 2). The applications in this first family are easy to use. They allow the user to geocode locations easily, to link the locations, especially in the form of trajectories, and to associate different kinds of media to the locations such as photos or videos. They are best designed for representing stories of trips or other nonfictional stories where locations and routes are clearly identified. 
Figure 1. Screenshot of OG's story map with Tripline

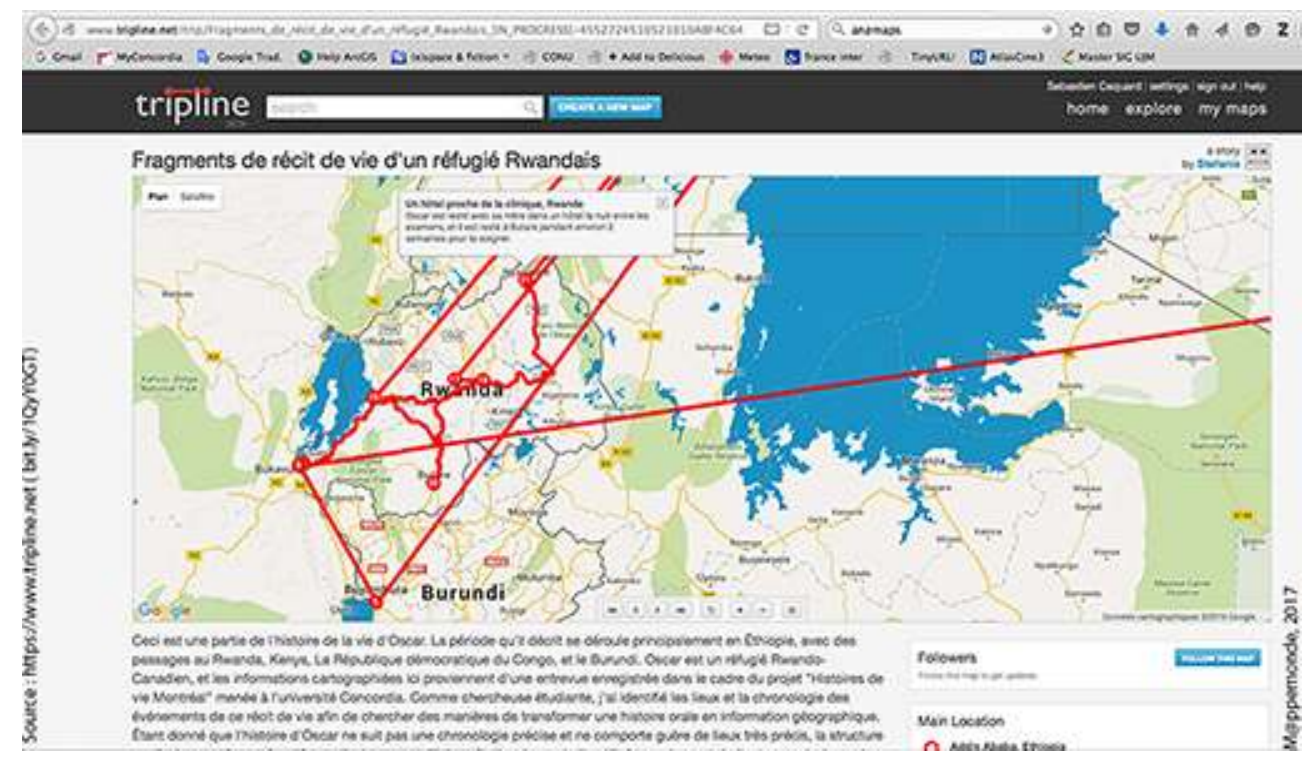

Map accessible online: bit.ly/1QyYOGT

Figure 2. Screenshot of OG's story map with Google Tour Builder

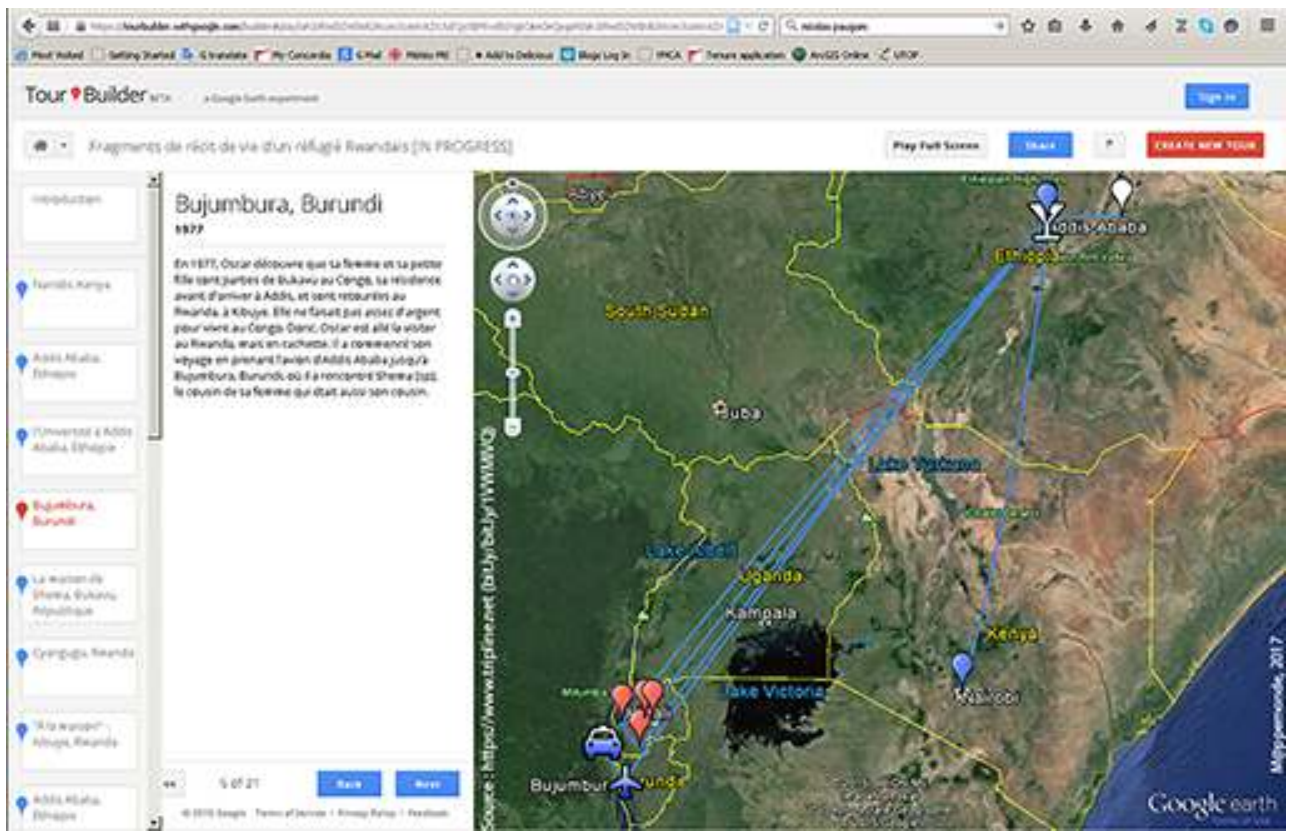

Map accessible online: bit.ly/1VWMIVQ

16 However, the ease of use comes with a price: these applications have limited cartographic options. The simplicity of the maps creates a visual uniformity, for both the locations as well as the links between them. These two applications therefore seem to visually level out any of the salient emotional, financial, and social aspects of stories. All of the locations appear more or less identical, whereas they often evoke difFerent levels of importance and meaning in the story. This homogenization reinforces the idea that conventional cartographic representations are not suited for representing spatial and temporal "asperities" of a political, social, economic and/or personal nature, which 
are so important in life stories, and notably in refugee life stories (Choplin and Pliez 2011). These maps, as emphasized by Laura Palmer (2014) on Google maps in general, present a uniform world emptied of its difFerences, contestations and political actions. Though this tendency towards spatial homogenization appears problematic for mapping the life stories of refugees, it would be much less so for stories with lesser political or social connotations, such as stories of a touristic nature. This touristic orientation is indeed quite evident with Google Tour Builder since the application uses Google Earth, which offers a lot of touristic information (e.g. the locations of restaurants and hotels), as well as access to many photos and videos often depicting attractive landscapes. This type of representation emphasizes spectacular and idyllic landscapes intended for occidental tourists (Palmer 2014), rather than inhabited locations, on the exceptional over the quotidian. Through this, the maps made using this kind of application tend to approach what Harris (2015) defines as "thin maps" (as opposed to the previously described "deep map"), that is maps which privilege the superficial and the spectacular at the expense of a depth of analysis and intimate understanding of places. The touristic and curated location becomes a place to visit and consume (virtually as well as in person). This kind of representation supports the idea that Google maps produce a hyperreal perspective of places by representing them in an idealized way, rendering them more desirable than they may be in reality (Caquard 2013). As much as this type of application can map stories of a touristic nature, it appears just as inappropriate to map life stories of refugees in which the "dense points" of these stories is not defined by any sort of spectacular dimension of a place, but rather by an intimate connection that an individual or group of individuals has with a place.

\section{The multifunctional applications}

The second family consists of applications that can be characterized as multifunctional, or those that can both tell stories with the assistance of a map as well as map stories for analytical purposes. MapStory and ESRI Story Maps are a part of this family. They both ofFer a wider range of options for mapping diverse kinds of stories, which probably explains their success (738 maps published by MapStory and 894 with ESRI Story Maps, as of February 15th 2015). These applications distinguish themselves from the previous ones on several levels: they offer the possibility of importing shapefiles, of representing quantitative data, of creating maps collaboratively, of representing difF erent stories on the same map (even if this might require a few adjustments) and of representing different types of links between places. These applications therefore ofF er a greater diversity of options for representing the diversity of experiences associated to the places that mark these stories.

The two applications of this family do difFer in many ways. For one, ESRI Story Maps is easier to use than MapStory. It also ofFers more cartographic options (especially for communicating spatial approximation), and it allows the user to produce maps with a higher graphic quality (see figure 3). ESRI Story Maps also benefits from the analytic functions of ArcGIS and allows the user to access a wide range of geographical data online through the intermediary of ArcGIS Online. Finally, ESRI Story Maps ofFers difF erent pre-developed cartographic models to cater to different kinds of projects. Regarding MapStory, its main advantage is the more sophisticated options for 
temporality since it includes the option for an interactive timeline (see figure 4) these elements are not found in ESRI Story Maps. Moreover, MapStory is inspired by a different philosophy, since it is an open-source tool made for developing maps that address contemporary social and environmental issues. However, beyond these difF erences, these two applications offer an interesting combination between a cartographic story and the cartographic analysis of a story, with a more robust cartographic toolbox than the previous family.

Figure 3. Screenshot of OG's story map using ESRI Story Maps

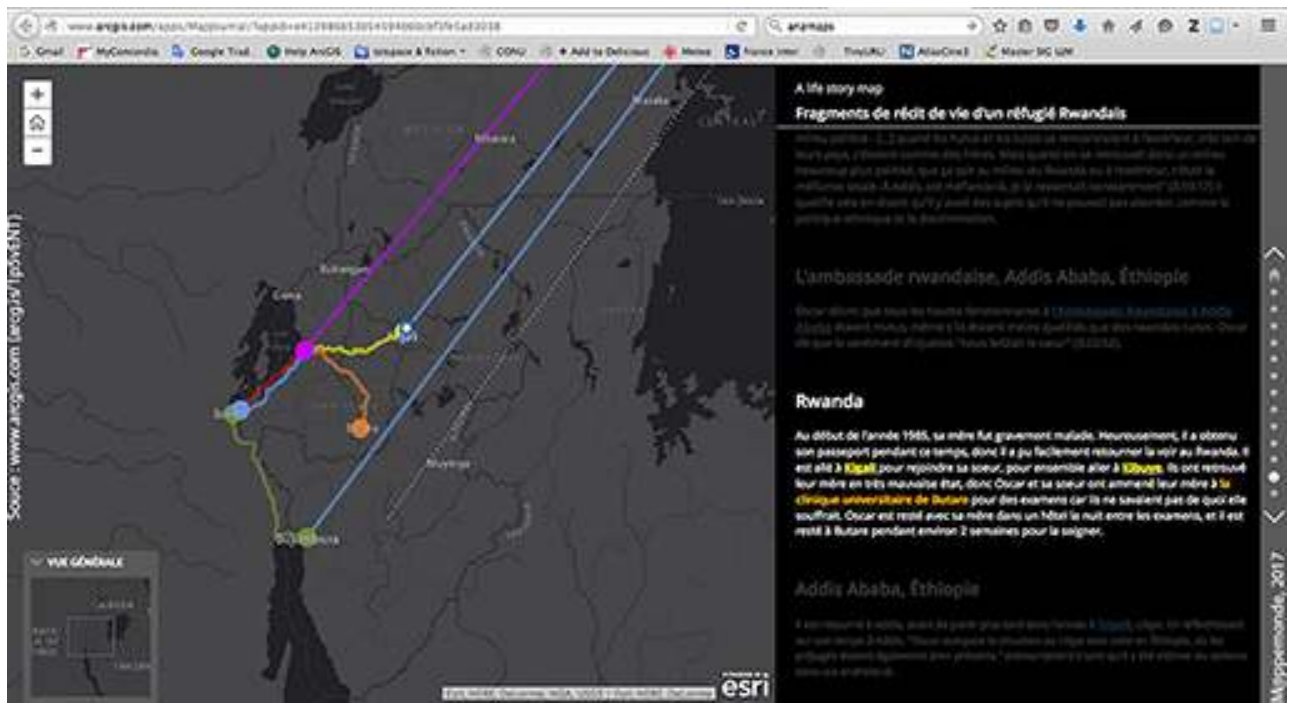

Map accessible online: arcg.is/1p5vENT

Figure 4. Screenshot of OG's story map with MapStory

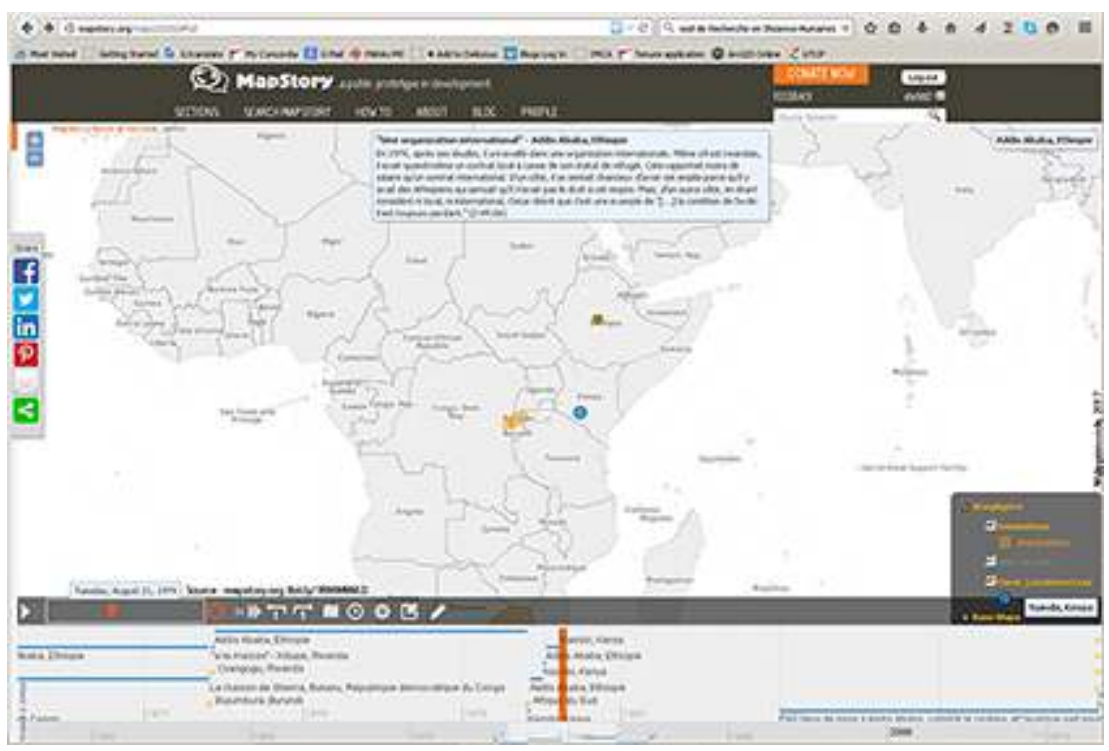

Map no longer available online: MapStory underwent a major upgrade in 2015-16 and since then it appears that our StoryLayers were erased. 


\section{Applications for story analysis}

The third family consists of story mapping applications that have a more analytical purpose. Here we find the last two applications in our selection: Atlascine, primarily dedicated to more spatial analyses (see figure 5), and Neatline, conceived for more temporal analyses and for navigating collections of artifacts and historical data (See fi gure 6). These two applications share some commonalities. They were both developed in an academic context, and are more complex to use compared to the previous applications which perhaps explains the limited examples available online (26 maps listed for Atlascine and 14 for Neatline, as of February 15, 2015). Their main advantage is in how they provide specific functions that address clearly defined objectives. Atlascine is dedicated to the spatial and structural analysis of stories. Most notably, it allows the automatic representation of the time associated to each location in the form of a playable timeline with proportional symbols that grow over time, as well as difF erent links between locations generated automatically (Caquard and Fiset 2014). It also makes it possible to include multiple stories in one map, thus promoting the visualization of "dense points" (des "points denses") common to multiple stories, in the words of Piera Rosetto $(2014,89)$. However, it does not ofFer any multimedia options.

Figure 5. Screenshot of OG's life story with Atlascine

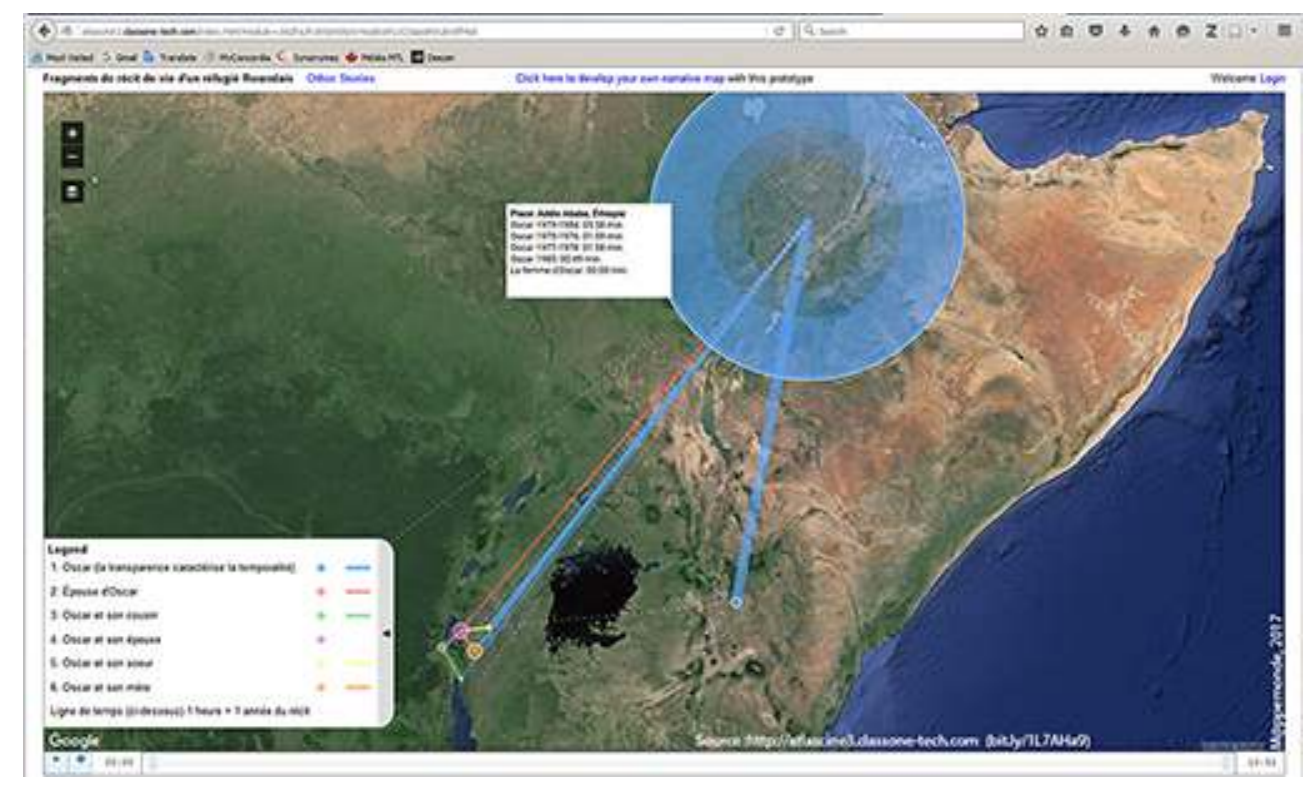

Map accessible online: bit.ly/1L7AHa9 
Figure 6. Screenshot of OG's story map using Neatline

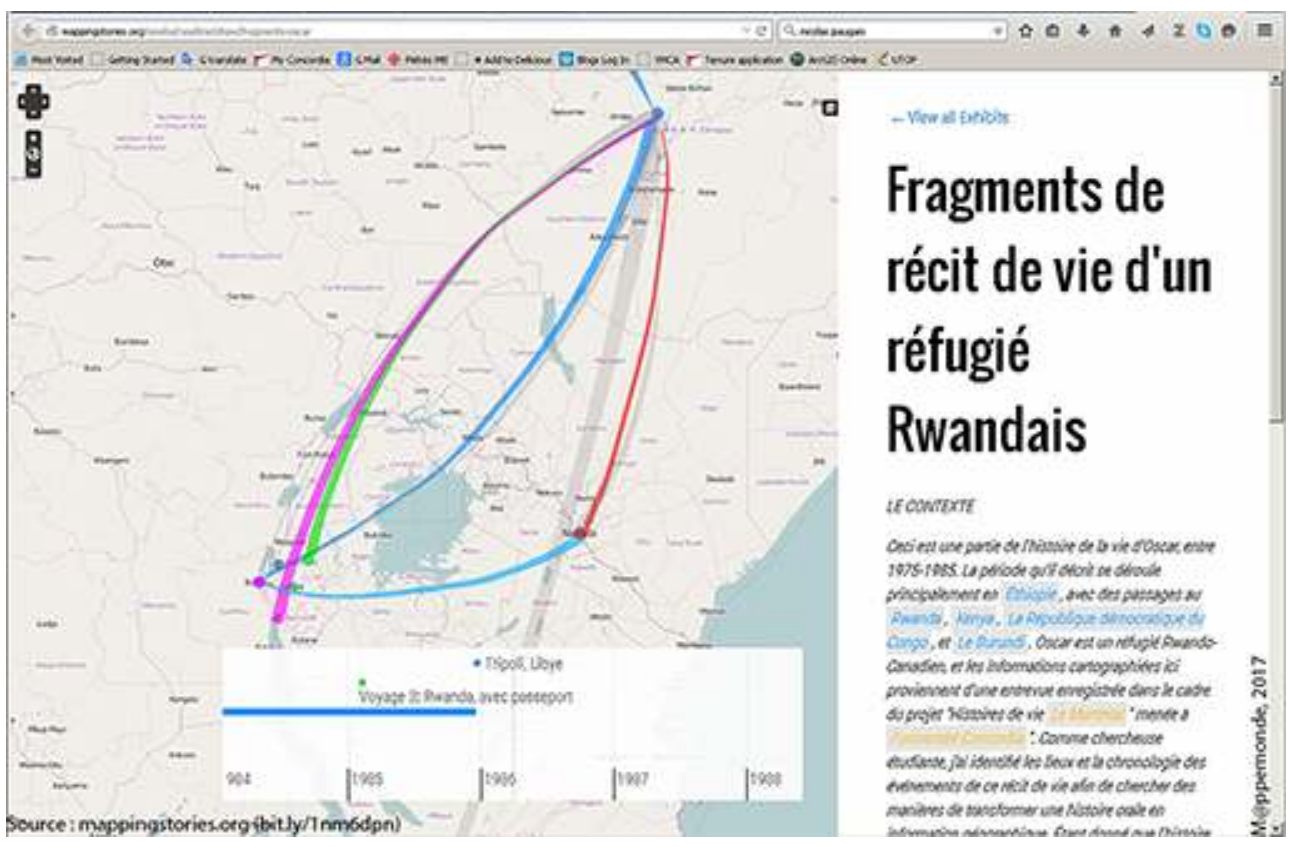

Map accessible online: bit.ly/1nm6dpn

21 In comparison, Neatline, created for archiving and exhibiting digital artifacts, allows the user to organize and structure these artifacts spatially and temporally. The map therefore becomes the primary means of navigating single stories or collections of stories, while facilitating the emergence of spatial structures. Neatline subscribes to the field of the digital humanities and deep mapping by explicitly opposing the superficial analysis of massive databases (Nowviskie et al. 2013). However, this kind of deep mapping is also more time-consuming, since Neatline requires a significantly longer learning period as compared to the other applications (approximately 30 hours instead of a dozen hours for the others). Also, Neatline is more of a graphical mapping tool off ering great flexibility in modes of representation, but little automated cartographic functionality in these representations.

\section{Synthesis}

This analysis allowed us to formulate some recommendations. For those interested in mapping stories of clearly identified locations and trajectories quickly and efFiciently, there are two main options: Tripline with its user-friendliness, its open-source philosophy, and its well thought-out toolkit, and Google Tour Builder, which has limited tools, but whose main advantage is the use of Google Earth and its associated services. Google Tour Builder seems best suited for touristic stories, as well as any projects that can benefit from the powerful tools offered by Google Earth.

For the more adventurous user, ESRI Story Maps ofFers more options (even more so if we include what is available with ArcGIS online) as well as a more sophisticated graphic interface. Although ideal for representing a wide range of stories, this application lacks temporal functionalities. If temporality is fundamental to the story map experience and if the subject matter has more social, political or environmental dimensions, Mapstory is definitely an application to consider. It is an open-source application which offers 
many options but is slightly more difficult to use than ESRI Story Maps, and has a less polished graphic result.

If the objective is to engage in mapping as a heuristic approach for analysing the spatial, temporal and/or narrative structure of stories, Atlascine is probably the most appropriate application. It allows the user to automatically represent the length of time associated to each moment in a story, as well as the locations in common between multiple stories. However, the data must be structured in a particular way, and mastering the use of this application requires slightly more time than the previous applications. However, Atlascine does not offer any multimedia options. Finally, if the objective is to archive and showcase a collection of digital artifacts in order to analyze and/or disseminate them, Neatline seems to be best suited for this. It is an open-source application that ofFers many graphic options, but few geographic options (for example it allows the user to create symbols but doesn't include a geocoder), and requires signifi cantly more time and computer skills to use properly. It is an application designed for long-term projects of a historical dimension.

\section{Conclusion}

This comparative analysis consisted of examining the potentialities of tools dedicated to mapping stories online. This qualitative analysis permitted us to see the emergence of three families of cartographic applications: simple applications that allow the user to represent stories in a uniform way (e.g. Tripline and Google Tour Builder); applications that are more sophisticated and more linked with the GIS world, allowing not only the telling of stories with maps but also the spatiotemporal analysis of stories (e.g. ESRI Story Maps and MapStory); and finally, applications geared primarily for research that employs stories as databases that can be analyzed in order to help better understand places, their intimate and personal geographies, as well as the structure of the stories that refer to those places (ex: Atlascine and Neatline).

Beyond the various features offered by these applications, their potential is directly in fluenced by the quality of the methodology used to convert stories into mappable data. Nevertheless, regardless of the chosen methodology, the use of these applications involves a predominance of Euclidean space over all other forms of space, including for the imagined experiences and spaces that structure stories. From a deep mapping perspective, the inclusion of these types of spaces appears essential to reveal the deeper meaning given to places through stories. Technological maps made using the tools presented here can therefore be completed by including a more sensitive approach - in the words of Elise Olmedo (2011). This approach could be achieved by ofF ering the possibility to the storytellers themselves to make their own maps in collaboration with artists, as has already been done (see Mekdjian et al. 2014). In so doing, perhaps empirical, technological maps and personal, artistic maps could be envisioned not as contradictory, as has been the case in the recent history of cartography, but as complimentary in understanding places through stories. 


\section{BIBLIOGRAPHY}

BODENHAMER D.J. (2015). « Narrating Space and Place ». In Bodenhamer D., Corrigan J., Harris T. M., Deep Maps and Spatial Narratives, Bloomington: Indiana University Press, p. 7-27. ISBN 978-0-253-01567-9

BODENHAMER D.J., CORRIGAN J. HARRIS T.M. (2015). « Introduction ». In Bodenhamer D., Corrigan J., Harris T. M., Deep Maps and Spatial Narratives, Bloomington: Indiana University Press, p. 1-6. ISBN 978-0-253-01567-9

CAQUARD S. (2013). « Cartography I. Mapping narrative cartography ». Progress in Human Geography, vol. $37, \mathrm{n}^{\circ} 1$, p. 135-144.

CAQUARD S., FISET J.-P. (2014). « How can we map stories? A cybercartographic application for narrative cartography ». Journal of Maps, vol. 10, n 1, p. 18-25.

CHOPLIN A., PLIEz O. (2011). « De la difFIculté de cartographier l'espace saharo-sahélien ». M@ppemonde, $\mathrm{n}^{\circ}$ 103. https://mappemonde-archive.mgm.fr/num31/intro/intro2.html COOPER D., GREGORY I.N. (2011). « Mapping the English Lake District: a literary GIS ». Transactions of the Institute of British Geographers, vol. 36, $\mathrm{n}^{\circ}$ 1, p. 89-108.

CRESSWELL T. (2004). Place: A Short Introduction. Malden, MA: Wiley-Blackwell, 168 p. ISBN 9781405106726

EVANS C., JASNOW B. (2014). « Mapping Homer's Catalogue of Ships ». Literary and Linguistic Computing, vol. 29, $\mathrm{n}^{\circ} 3$, p. 317-325.

HARRIS T.M. (2015). « Deep geography - Deep Mapping: Spatial Storytelling and a Sense of Place». In Bodenhamer D., Corrigan J., Harris T. M., Deep Maps and Spatial Narratives, Bloomington: Indiana University Press, p. 28-53. ISBN 978-0-253-01567-

HUI B. (2009) Litmap Presentation Notes. http://barbarahui.net/about-litmap.html (Accessed May 11, 2017).

KNOWLES A.K., WESTERVELD L., STROM L. (2015). « Inductive Visualization: A Humanistic Alternative to GIS ». GeoHumanities, vol. 1, n² 2, p. 233-265. doi:10.1080/2373566X.2015.1108831

KWAN M.-P., DING G. (2008). « Geo-Narrative: Extending Geographic Information Systems for Narrative Analysis in Qualitative and Mixed-Method Research ». The Professional Geographer, vol. $60, \mathrm{n}^{\circ} 4$, p. $443-465$.

LITTMAN A. (2011). Wounded Land. https://ariane-littman.com/2009/08/wounded-landmaps-2009-2013/?setslidercat=wounded-land (Accessed May 11, 2017).

MASSEY D.B. (2005). For space. Londres: SAGE, 232 p. ISBN 9781412903622

MEKDJIAN S., AMILHAT-SZARY A.-L., Moreau M. et al. (2014). « Figurer les entre-deux migratoires. Pratiques cartographiques expérimentales entre chercheurs, artistes et voyageurs ». Carnets de géographes, $\mathrm{n}^{\circ}$ 7, « Les espaces de l'entre-deux », Julie Le Gall and Lionel Rougé (dir.).

MORETTI F. (1999). Atlas of the European novel, 1800-1900. London: Verso, 206 p. ISBN 9781859842249

MORETTI F. (2005). Graphs, Maps, Trees: Abstract Models for Literary History. London: Verso, 119 p. ISBN 9781844670260 
NARAMORE Maher N. (2014). Deep Map Country. Literary Cartography of the Great Plains. Lincoln: University of Nebraska Press, 256 p. ISBN 978-0803245020

NOWVISKIE B., McClure D., Graham W. et al. (2013). « Geo-Temporal Interpretation of Archival Collections with Neatline ». Literary and Linguistic Computing, vol. 28, n 4, p. 692-699.

OLMEDO É. (2011). «Cartographie sensible, émotions et imaginaire ». Visions cartographiques - Les blogs du Diplo. https://blog.mondediplo.net/2011-09-19-Cartographie-sensible-emotions-etimaginaire

PALMER L. (2014). « Ushahidi at the Google Interface: Critiquing the "geospatial Visualization of Testimony” ». Continuum, vol. 28, n 3, p. 342-356. doi :10.1080/10304312.2014.893989

PEARCE M.W., HERMANN M.J. (2010). « Mapping Champlain's Travels: Restorative Techniques for Historical Cartography ». Cartographica: The International Journal for Geographic Information and Geovisualization, vol. $45, \mathrm{n}^{\circ}$ 1, p. 32-46.

PIATTI B., BÄR H., REUSCHEL A., HURNI L., CARTWRIGHT W. (2009). « Mapping Literature: Towards a Geography of Fiction ». In Cartwright W., Gartner G., Lehn A. (éd.), Cartography and Art. Berlin/ Heidelberg: Springer, « Lecture Notes in Geoinformation and Cartography », p. 177-192.

ROSSETTO P. (2014). « Juifs de Libye : notes pour une "cartographie" des lieux migratoires ». Archivio Antropologico Mediterraneo, vol. 16, n 1, p. 87-99.

ROSSETTO T. (2014). « Theorizing maps with literature ». Progress in Human Geography, vol. 38, n 4, p. 513-530.

SEEMANN J. (2012). « Cartographic-story-telling, performance of way-finding and (e)motional mapping in the Cariri region, State of Ceará ». Boletim de Geografia, vol. 30, n² 2, p. 5-13.

SENGES P. (2011). Environs et mesures. Paris : Gallimard, 112 p. ISBN 9782070133383

WELLS A. (2012). « La cartographie comme outil d'analyse littéraire : des cartes métaphoriques aux cartes SIG ». In Maleval V., Picker M. et Gabaude F. (dir.), Géographie poétique et cartographie littéraire, Limoges : PULIM, p. 169-186.

WooD D. (2015). « Mapping Deeply ». Humanities, vol. 4, $\mathrm{n}^{\circ}$ 3, p. 304-318. Notes

\section{NOTES}

1. The two applications that were not included in the analysis were Trippermap and Maptia. Trippermap was not included because after several attempts we were not able to create a map (and we did not get answers to questions sent to the email available on the website of this application). Maptia was tested, but was not included in the end because of the marginal role of the map in the application. 


\section{ABSTRACTS}

This article offers a comparative analysis of six applications for mapping narratives on the Internet. Based on the life story of a Rwandan refugee, three main families of cartographic applications were identified: simple applications that allow the user to map stories in a standard format (ex: Tripline and Google Tour Builder); more sophisticated applications directly linked to the world of GIS), which allow the user to tell various stories using maps but which also use maps as tools for spatial and temporal analyses (ex.: ESRI Story Maps, MapStory); finally, applications that are more research oriented using narratives as databases whose analyses can help us better understand the places, their personal and intimate geographies, and the structures of the narratives that refer to them (ex.: Atlascine et Neatline).

Cet article propose une analyse comparative de six applications dédiées à la cartographie des récits sur Internet. À travers la mise en carte du récit de vie d'un réfugié rwandais, trois grandes familles d'applications cartographiques ont été identifiées : les applications simples permettant de représenter cartographiquement des histoires de manière uniformisée (par exemple, Tripline et Google Tour Builder) ; les applications plus sophistiquées et plus directement liées au monde des SIG permettant non seulement de raconter des histoires variées à l'aide de cartes, mais aussi d'utiliser la carte comme outil d'analyse spatiotemporelle des récits (par exemple, ESRI Story Maps et MapStory); enfin les applications plus orientées vers la recherche qui abordent les récits comme autant de bases de données dont l'analyse peut nous aider à mieux comprendre les lieux, leurs géographies intimes et personnelles, ainsi que la structure des récits qui s'y réfèrent (par exemple, Atlascine et Neatline).

Este artículo analiza y compara tres tipos de aplicaciones para representar mediante mapas temáticos relatos en internet. Cartografiando las vivencias de un refugiado ruandés, se han analizado tres tipos de aplicaciones : las simples, que cartografían narrativas de manera uniforme (como Tripline o Google Tour Builder); las más sofisticadas que trabajan con sistemas de información geográfica, y que permiten, además de gerorreferenciar los relatos, y utilizar el mapa como un instrumento de análisis espaciotemporal (ESRI Story Maps; MapStory); y finalmente aquellas aplicaciones orientadas hacia la investigación, que gestionan estos relatos como bases de datos para analizar y comprender mejor sus estructuras, los espacios, y las geografías más emocionales y personales (como Atlascine o Neatline).

\section{INDEX}

Subjects: La mise en carte des récits

Mots-clés: cartes profondes, cartographie des récits, ESRI Story Maps, Géoweb, récits de vie

Palabras claves: cartografías narrativas, Geoweb, cartografías complejas, vivencias o historias de vida

Keywords: cartography of narratives, Geoweb, Deep maps, Life narratives, ESRI Story Maps

\section{AUTHORS}

\section{SÉBASTIEN CAQUARD}

Université Concordia, Montréal 